\title{
Strategi Pemenuhan Kebutuhan Hidup Single Parent
}

\author{
Sukman \\ St. Fatimah Tola \\ Universitas Muhammadiyah Makassar \\ fatimahtola@unismuh.ac.id \\ Nurdin \\ Universitas Muhammadiyah Makassar \\ nurdin@unismuh.ac.id
}

\begin{abstract}
ABSTRAK
Strategi Pemenuhan Kebutuhan Hidup Single Parent Masyarakat Lilirilau Kabupaten Soppeng. Rumusan masalah dari penelitian ini adalah bagaimana strategisingle parent dalam memenuhi kebutuhan hidup di lilirilau kabupaten soppeng dan apakah masalah yang dihadapi olehsingle parent dalam memenuhi kebutuhan hidup di lilirilau kabupaten soppeng Penelitian ini bertujuan untuk mengetahui strategisingle parent dalam memenuhi kebutuhan hidup di lilirilau kabupaten soppeng dan untuk mengetahui masalah yang dihadapi olehsingle parent dalam memenuhi kebutuhan hidup di lilirilau kabupaten soppeng. Jenis penelitian ini adalah metode kualitatif deskriptif, pengumpulan data digunakan dengan cara observasi, wawancara mendalam, dan dokumentasi. Dalam penelitian ini, yang menjadi sasaran penelitian adalah pertama keluarga single parent di kecamatan lilirilau kabupaten soppeng, kedua masyarakat yang dianggap bisa memberikan informasi atau data yang sesuai dengan penelitian. Hasil penelitian ini menunjukkan bahwa, suatu strategi yang di lakukan oleh single parent untuk memenuhi kebutuhan hidupnya yaitu dengan melakukan kerja sampingan selain itu cara yang dilakukan dengan mengambil pinjaman kepada tetangga. Berdasarkan hasil penelitian tentang strategi pemenuhan kebutuhan hidup maka single parent di tuntut untuk bekerja keras untuk menafkahi keluarganya.
\end{abstract}

Kata Kunci: Strategi, Single Parent, Masyarakat.

\section{PENDAHULUAN}

Keluarga merupakan lembaga sosial yang paling kecil dan merupakan lembaga dalam masyarakat yang paling dasar. Dimana proses pengenalan jati diri serta proses sosialisasi yang pertama kali dilakukan, maka dari proses sosialisasi di dalam keluarga itulah seseorang akan memiliki bekal untuk dapat berinteraksi dan bersosialisasi dengan lembaga sosial yang lebih besar yaitu masyarakat. Pada dasarnya keluarga adalah orang yang disatukan oleh ikatan-ikatan perkawinan.Keluarga merupakan kesatuan dari orangorang yang berinteraksi dan berkomunikasi yang menciptakan peranan-peranan sosial bagi suami, istri dan anak.Dimana keluarga inti terdiri dari ayah, ibu dan anak $(\mathrm{H}$. Khairuddin, 1985 :14). Belakangan ini dengan berkembangnya kebudayaan, akan mempengaruhiproses sosialisasi pada keluarga masa kini sering terjadi pada zamansekarang ini yaitu perceraian, terjadinya perceraian maka dengan sendirinya 
fungsikeluarga akan mengalami gangguan dan pihak yang bercerai harus dapatmenyesuaikan diri dengan situasi yang baru. Sehingga terbentuklah keluarga yang bercerai,seperti hidup sendiri menjanda atau menduda, yang pada akhirnya menimbulkan efekterganggunya psikis seorang anak yang harus memilih hidup dengan siapa (ayah atauibu).Fenomena ini lazim disebut sebagai salah satu bentuk keluarga single parent.Single Parent merupakan keluarga yang terdiri dari orang tua tunggal baikayah atau ibu sebagai akibat perceraian dan kematian.Single parent juga dapat terjadipada lahirnya seorang anak tanpa ikatan perkawinan yang sah dan pemeliharaannyamenjadi tanggung jawab itu. Ada beberapa faktor yang mempengaruhi status singleparent. Faktorfaktor tersebut antara lain: perceraian, Kematian, Orang tua angkat, Orang tua berpisah tempat tinggal / belum bercerai (Hendi, Dkk. 2001:141).Sehingga melihat dari latar belakang diatas, maka penulis merasa tertarikuntuk melakukan penelitian mengenai kehidupansingle parent.

\section{LANDASAN TEORI}

Definisi strategi adalah cara untuk mencapai tujuan jangka panjang. Strategi bisnis bias berupa perluasan geografis, diversifikasi, akusisi, pengembangan produk, penetrasi pasar, rasionalisasi karyawan, divestasi, likuidasi dan joint venture.Pengertian strategi adalah Rencana yang disatukan, luas dan berintegrasi yang menghubungkan keunggulan strategis perusahaan dengan tantangan lingkungan, yang dirancang untuk memastikan bahwa tujuan utama dari perusahaan dapat dicapai melalui pelaksanaan yang tepat oleh organisasi.

Strategi adalah pendekatan secara keseluruhan yang berkaitan dengan pelaksanaan gagasan, perencanaan, dan eksekusi sebuah aktivitas dalam kurun waktu tertentu. Di dalam strategi yang baik terdapat koordinasi tim kerja, memiliki tema, mengidentifikasi faktor pendukung yang sesuai dengan prinsip-prinsip pelaksanaan gagasan secara rasional, efisien dalam pendanaan, dan memiliki taktik untuk mencapai tujuan secara efektif. Strategi dibedakan dengan taktik yang memiliki ruang lingkup yang lebih sempit dan waktu yang lebih singkat, walaupun pada umumnya orang sering kali mencampuradukkan ke dua kata tersebut.Perumusan Strategi Perumusan strategi merupakan proses penyusunan langkah-langkah ke depan yang dimaksudkan untuk membangun visi dan misi organisasi, menetapkan tujuan strategis dan keuangan perusahaan, serta merancang strategi untuk mencapai tujuan tersebut dalam rangka menyediakan customer value terbaik. 
Strategi penghidupan rumah tangga diadopsi dari Teori White adalah strategi kelangsungan hidup (survival strategy) yang pada umumnya miskin atau marjinal dicirikan oleh kepemilikan aset sumber daya lahan yang sempit maupun modal yang terbatas.Tumpuan pendapatan diandalkan pada curahan tenaga dengan keterampilan yang terbatas pula. Status baru yang disandang sebagai ayah atau ibu tunggal cukup menjadi alasan untuk memenuhi kebutuhan dalam hidup dengan suatu usaha dan cara tertentu. Teori Strategi selanjutnya merupakan teori strategi kelangsungan rumah tangga (household survival strategy) menurut teori ini, dalam masyarakat pedesaan yang mengalami transisi dan golongan miskin di kota.

Single berarti satu atau sendiri dan parent berarti orang tua tunggal.Single parent adalah keluarga yang terdiri dari orang tua tunggal baik ayah atau ibu sebagai akibat perceraian dan kematian.Single parent dapat dapat terjadi pada lahirnya seseeorang anak tanpa ikatan perkawinan yang sah dan pemeliharaannya menjadi tanggung jawab itu.Pada umumnya keluarga terdiri dari ayah, ibu, dan anak-anak. Ayah dan ibu berperan sebagai orang tua bagi anak-anaknya. Namun,dalam kehidupan nyata sering dijumpai keluarga dimana salah satuorang tuanya tidak ada lagi. Keadaan ini menimbulkan apa yangdisebut dengan keluarga dengan single parentMenurut Hurlock (1999: 199) orangtua tunggal (single parent)adalah orangtua yang telah menduda atau menjanda entah bapak atauibu, mengasumsikan tanggung jawab untuk memelihara anak-anaksetelah kematian pasangannya, perceraian atau kelahiran anak diluarnikah.Berdasarkan berbagai definisi di atas, dapat disimpulkan bahwakeluarga dengan single parent adalah keluarga yang hanya terdiri dari satu orang tua yang dimana mereka secara sendirian membesarkan anakanaknya tanpa kehadiran, dukungan, tanggung jawab pasangannya dan hidup bersama dengan anak-anaknya dalam satu rumah..

Kajian teori yang digunakan dalam penelitian ini adalah dengan menggunakan teori struktural fungsional, yang mengatakan suatu masyarakat sebagai suatu system yang terdiri dari sub sistem yang saling berhubungan antara satu dengan yang lainnya.Dengan teori ini sebuah keluarga dianggap memiliki bagian yang terdiri dari adanya seorang ayah, seorang ibu, adanya anak-anak dan anggota keluarga lainnya. Setiap anggota disini dianggap sub sistemnya, yang tiap anggotanya memiliki fungsi masing- masing. Fungsi tersebut membawa konsekuensi tertentu bagi anggota keluarga dan bagi keluarga secara keseluruhan. Dalam hal ini dengan ketiadaan figur seorang ayah maka peranannya pun akan digantikan oleh seorang ibu, dengan begitu tentu saja akan merubah fungsi-fungsi yang ada di dalam keluarga tersebut, dan akan membawa konsekuensi bagi para anggota 
yang ada didalamnya.Selain itu juga menggunakan teori gender.Gender adalah suatu istilah yang digunakan untuk menggambarkan pembedaan antara laki-laki dan perempuan secara sosial. Gender adalah kelompok atribut dan perilaku yang dibentuk secara kultural yang ada pada laki-laki dan perempuan.Gender adalah konsep hubungan sosial yang membedakan (memilahkan atau memisahkan) fungsi dan peran antara laki-laki dan perempuan.Pembedaan fungsi dan peran antara laki-laki dan perempuan itu tidak ditentukan karena keduanya terdapat perbedaan biologis atau kodrat, melainkan dibedakan menurut kedudukan, fungsi, dan peranan masing-masing dalam berbagai bidang kehidupan dan pembangunan.

\section{METODE PENELITIAN}

Jenis penelitian yang dilakukan penelitian kualitatif yang bertujuan memahami strategi pemenuhan kebutuhan hidup single parent)di wilayah kecamatan Lilirilau Kabupaten Soppeng., Instrumen penelitian adalah peneliti sendiri dan alat bantu yang lain seperti lembar observasi dan kamera. Informan ditentukan secara purposive sampling yaitu masyararakat di desa Abbanuange sebanyak 10 orang dan masyarakat di Desa Tetewatu sebanyak 7 orang total 17 orang.teknik pengumpulan data yaitu observasi, wawancara dan dokumntasi, kemudian dianalisis melalui tahapan pengumpulan data (data collection), reduksi data (data reduction), penyajian data data display), data yang dikelompokan, penarikan kesimpulan (conclusion) dan menggunakan teknik keabsahan data triangulasi sumber, waktu, dan teknik.

\section{PEMBAHASAN}

Melaksanakan fungsi keluarga setiap anggota keluarga mempunyai peranmasingmasing sesuai dengan status keluarga.Fungsi-fungsi yang dilakukan olehanggota keluarga menunjukkan bahwa adanya ikatan antara masing-masing anggotakeluarga dalam melaksanakan fungsi keluarga agar kehidupan menjadi harmonisdalam meningkatkan kesejahteraan keluarga.

1) Fungsi Sosialisasi

Sosialisasi dapat juga dikatakan suatu proses, yang berarti bahwa iamerupakan suatu gejala perubahan, gejala penyesuaian diri, gejala pembentukan,gejala-gejala mana yang terjadi didalam masyarakat dengan individu maupunsebaliknya. Semua gejala ini disebabkan karena individu-individu dalam kelompokmenyesuaikan diri satu sama lain, menyesuaikan diri dengan keadaan. Anakmemperoleh sosialisasi yang pertama di 
lingkungan keluarga.Orang tua berperanuntuk mempersiapkan anak agar menjadi anggota masyarakat yang baik. Dalam suatu keluarga melalui proses sosialisasi inilah setiap anak atau individu dapat berinteraksi dengan sesamanya seperti orang tua, kakak, abang maupun anggota kerabat lainnya.Sekaligus belajar untuk memahami perannya dalam sebuah keluarga sebelum masukke dalam kelompok yang lebih besar.Kematian pasangan jelas berpengaruh terhadap pelaksanaan fungsi sosialisasi keluarga, pasangan yang ditinggal terpaksa harus melakukan proses sosialisasinyasendiri. Namun walaupun demikian, kini hal itu tidak terlalu meresahkannya, karenadalam pelaksanaannya fungsi sosialisasi ini dibantu oleh lembaga-lembaga tertentuseperti sekolah, lingkungan tempat tinggal, tetangga dan lain sebagainya.fungsi sosialisasi penerapan nilai agama yang dilakukan oleh ibu single parent terhadap anak-anaknya. Sosialisasi nilai agama adalah pemberian pemahaman nilai-nilai agama kepada anak melaluipendidikan ibadah, pembentukan akhlak, dan lain sebagainya. Dapat dikatakan bahwatujuan dari sosialisasi nilai agama tersebut adalah untuk menanamkan nilai-nilaiagama kepada anak, supaya mereka dapat hidup dan menjalankan serta mempunyai kepribadian dan akhlak yang luhur sesuai dengan yang diharapkan orangtuanya dalam hal ini seperti pada ibadah shalat lima waktu.

Pada umumnya ibu single parentmengatakan bahwa mereka senantiasa mengingatkan kepada anaknya kewajibanmelaksanakan ibadah sholat lima waktu. Keseriusan tentang pentingnya sosialisasinorma agama kepada anak-anaknya memang sangat di terapkan oleh ibu singleparent tersebut, baik dari sanksi yang diberikan seperti memarahi atau memukuli anak-anaknya jika melihat anak-anaknya dengan sengaja meninggalkan sholat.Indikator lain yang memberikan gambaran tentang sosialisasi dalam keluargaibu single parent disini yaitu dengan adanya diskusi di dalam keluarga. Dimana yang dimaksudkan dengan diskusi disini adalah adanya komunikasi antara anak denganorang tua didalam menyelesaikan permasalahan yang terjadi didalam keluarga.Hal ini dikarenakan di dalam setiap langkah hidup keluarga, orang tua selalu diharapkan oleh anaknya dapat membimbing dan menunjukkan sikap yang baik.Hal ini semakin jelas tampak disaat fungsi keluarga sedang mengarah kepada kesamaan dankebersamaan. Unsur ini mendorong setiap anggota keluarga hidup berdampingan satu sama lain. Seorang anak harus dilibatkan dalam setiap pemecahan masalah dalam keluarga. Sebagai individu ia diberi kesempatan menyampaikan gagasan dan saransarannya. Tujuannya tidak lain hanya untuk mencapai tujuan dari keutuhan dan kebahagiaan keluarga.

2) Fungsi Afeksi 
Fungsi afeksi merupakan bagaimana keluarga memberikan hubungan sosialyang penuh dengan kemesraan, cinta kasih, kasih sayang dan kebahagiaan. Fungsi afeksi ini sangat penting bagi perkembangan pribadi anak (Khairuddin, 1985 : 205). Fungsi afeksi dalam keluarga tidak terlepas dari perlindungan orang tuakepada anakanaknya.Perlindungan secara ekonomi dan fisik tentu sudah dilakukanorang tua kepada anak-anaknya mulai dari kecil hingga anak benar-benar siap untuk hidup ditengah-tengah masyarakat. Kehidupan anak akan merasa nyaman bila kehadiran orang tua di setiap sisi kehidupan meskipun dalam intensitas yang terbatas.

Namun kembali lagi pada pokok pembahasan, bahwa tidak semua keluargahidup lengkap bersama seluruh anggota keluarganya.Seperti beberapa keluarga yang ada di Kecamatan Lilirilau Kabupaten Soppeng, terdapat beberapa keluarga yang tinggal hanya bersama satu orang tua saja yaitu ibu atau ayah.Fungsi afeksi didalam penelitian ini mencakup wujud kasih sayang yangdiberikan oleh ibu single parent kepada anak-anaknya yaitu dalam kegiatan yangdilakukan secara bersamasama.Selain dilihat dari kegiatan makan bersama, kegiatanmenemani anak dalam hal menonton televisi, menemani anak belajar juga dapat menciptakan rasa kebersamaan dan kasih sayang antar anggota keluarga.

3) Fungsi Proteksi

Fungsi proteksi adalah fungsi yang berhubungan dengan segala kebutuhan fisik anak yang mana semuanya bernilai praktis yang juga termasuk dalam hal perawatan anak.Salah satu fungsi keluarga adalah perlindungan.Fungsi perlindungan dapat dibagi tiga yaitu perlindungan fisik, ekonomi dan psikologis.Setiap anggota keluarga pasti membutuhkan ketiga hal tersebut. Fungsi proteksi juga mencakuptentang bagaimana orang tua dapat mengontrol dan mengawasi kegiatan-kegiatanyang dilakukan oleh anak, baik didalam rumah maupun diluar rumah dan juga mengenai kebutuhan anak yang bernilai praktis disini contohnya adalah peran ibudalam hal perawatan diri anak, kerapian dan kebersihannya, memperhatikan semua kegiatan yang dilakukan setiap hari, bekerja dan beristirahat dan melindungi anak dari rasa kurang aman atau ketakutan. Namun kehidupan dengan status keluarga Single Parent tersebut tentu akan mempengaruhi psikologis anak untuk berkembang. Anak-anak dari keluarga Single Parent tersebut tentu juga sangat mengharapkanperlindungan dari orang tua khususnya ayah.Sebagai bentuk pemberian perlindunganorang tua kepada anak dapat dilihat pada pemberian nasehatnasehat kepada anak. Dengan pemberian nasehat kepada anak maka akan menumbuhkan rasa nyaman danmerasa selalu diperhatikan oleh orang tua khususnya ayah. Namun kini 
pemberian nasehat tersebut bisa digantikan oleh seorang ibu karena ketiadaan seorang ayah tadi.Pemberian nasehat itu dapat berupa penanaman budi pekerti kepada anak sehingga anak hidup bermasyarakat sesuai dengan norma-norma dan nilai-nilai yang berlakudalam masyarakat tersebut.Pemberian nasehat yang dilakukan oleh ibu terhadap anak-anaknya dapat dilihat intensitasnya dalam rutinitas sehari-hari.

4) Fungsi Ekonomi

Fungsi ekonomi keluarga sangat penting bagi kehidupan, karena merupakan pendukung utama bagi kebutuhan dan kelangsungan dari suatu keluarga. Di dalam fungsi ekonomi tinggi rendahnya pendapatan suatu keluarga akan berpengaruh pada kehidupan keluarga tersebut. Jika pendapatan keluarga rendah maka akan berpengaruh kurang baik bagi anggota keluarga, karena dengan pendapatan yang rendah otomatis akan sulit untuk menyekolahkan anak-anak apalagi jumlah anggota yang harus ditanggung lebih banyak. Selain itu jika pendapatan keluarga rendah orang tua akan berpendapat bahwa kebutuhan panganlah yang pertama yang harus terpenuhi baru menyusul kebutuhan-kebutuhan lain.

Status ibu single parent yang kini juga menjadi kepala rumah tanggamenuntut ia sebagai pencari nafkah dan pengambil keputusan dalam keluarga. Dari hasil penelitian dilapangan ternyata ada juga anak-anak mereka yang sudah dewasa atau anggota keluarga lainnya juga berpartisipasi dalam membantu mencari nafkah untuk membantu perekonomian keluarga.Sehingga setiap anggota keluarga saling membantu tanpa adanya pembatasan yang tegas.Yang penting terwujudnya rasa saling pengertian.Hal ini dapat dibuktikan dengan adanya beberapa keluarga dimana seorang anak pun ikut serta dalam mencari nafkah guna mengatasi biaya hidup keluarga.

Berdasarkan hasil analisa data dari penelitian tentang strategi yang dilakukanoleh keluarga single parent disini dalam mengahadapi masalah yang muncul padasaat menjalankan fungsi keluarga, terdapat beberapa cara-cara yang dilakukan oleh ibu single parent yaituDari hasil temuan-temuan penelitian tentang strategi perempuan single parent dalam mengatasi masalah yang muncul pada saat menjalankan fungsi keluarga di Kelurahan Kecamatan Lilirilau Kabupaten Soppeng khususnya dalam hal masalah ekonomi yaitu melalui kerja keras yang dilakukan oleh ibu single parent. Seperti ada yang menjual Pisang, bawang, cabe dan lain-lain, ada juga yang menjual makanan di sekolah-sekolah, ada juga yang membuka lahan kosong untuk di garap, ada juga yang membangun kios-kios di depan rumahnya, ada juga yang membantu tetangganya bekerja kemudian di gaji, ada juga yang bekerja keras kemudian ada juga yang memang 
mendapatkan warisan dari suaminya dulu bahkan yang lebih ironis ada Single Parent relah meminjam uang kapada pedagang coklat. Semua pekerjaan tersebutdilakukan ibu single parent semata-mata untuk mencari nafkah guna memenuhi kebutuhan hidup keluarganya.

\section{KESIMPULAN}

1) Dalam masalah ekonomi, perempuan Single Parent masih harus bekerja keras dalam memenuhi kebutuhan keluarga. Hal tersebut dikarenakan oleh pekerjaan mereka yang masih rendah sehingga pendapatan yang diterima pun sedikit, sedangkan kebutuhan semakin hari semakin meningkat, hal itulah yang paling dominan menjadi masalah bagi perempuan Single Parent.

2) Usaha yang dilakukan Single Parent untuk menambah ekonomi keluarganya, seperti menjual pisang, bawang, cabe dan lain-lain, kemudian menjual makanan di sekolah, membangun kios penjualan, bahkan meminjam uang kepada pedagang coklat.

3) Untuk menghidupi keluarga, Single Parent bekerja seperti membuka lahan kosong untuk di garap, membantu tetangga, bekerja keras kemudian ada yang mendapatkan warisan dari suami sebelumnya.

\section{DAFTAR PUSTAKA}

Abdulsyani.,(2002). Sosiologi: Skematika, Teori, dan terapan. Jakarta: PT. Bumi Aksara.

Bagong Suyanto dan J. Dwi Narwoko., (2004)Sosiologi Teks Pengantar dan Terapan. Surabaya: Kencana.

Bertrand, L. Alvin., (1980). Sosiologi Kerangka Acuan, Metode Penelitian TentangSosialisasi Dan Kebudayaan. Surabaya: Bina Ilmu.

Dr. Indrayani, S.E., M.M dan Prof. Dr. Damsar., (1998). Pengantar Sosiologi Ekonomi. Jakarta: PT. Raja Grafindo Persada.

Fahrudin,Adi.,. (2012) Pengantar Kesejahteraan Sosial, Bandung: PT Refika Aditama.

Goode, William J., (1991).Sosiologi Keluarga. Jakarata: Bumi Aksara.

Ishak, Isjoni.,(2002). Masyarakat Dan Perubahan Sosial. Pekanbaru: UNRI Press.

Jhon B Miner dan George A Steiner., (1985) .Kebijakan dan Strtegi Manajemen.Surabaya: Penerbit Erlangga.

Karim, Rusli M., (1982) Seluk Beluk Perubahan Sosial Surabaya. Usaha Nasional. 
Khairuddin., H. (2002). Sosiologi Keluarga. Yogyakarta: Liberty.

Klemens, Mau, Yoseph.,(2006). Perceraian dan Peran Single-Parent Perempuan.Semarang: Program Pasca Sarjana Universitas Diponegoro Semarang.

Kuswardinah, Asih.,(2007). Ilmu Kesejahteraan Keluarga. Semarang: UNNES Press.

Paizaluddin, Ermalinda.,(2013). Penelitian Tindakan Kelas Pamduan Teoritis \& Praktis.Bandung: Alfabeta.

Patilima, Hamid.,(2011). Metode Penelitian Kualitatif. Bandung: Alfabeta.

Shadily, Hasan.,(1993). Sosiologi Untuk Masyarakat Indonesia.Jakarta: Rineka Cipta.

Soehartono, Dr, Irawan.,(1995). Metode Penelitian Sosial: Suatu Teknik Penelitian Bidang Kesejahteraan Sosial dan Ilmu Sosial Lainnya. Bandung: PT. Remaja Rosdakarya.

Soekanto, Soerjono.,(1990) Sosiologi Suatu Pengantar. Jakarta: Rajawali.

Suhendi., Hendi., (2001). Pengantar Studi Sosiologi Keluarga. Bandung: Pustaka Setia.

Syani, Abdul.,(1994) Sosiologi Suatu Skematika Teori dan Terapan. Jakarta: Cetakan Pertama Bumi Aksara Bandar Lampung.

Vago, Steven.,(1996) Teori Perubahan Sosial. New Jersey: terjemahan Aliman dan Presentice Hall inc.

Aliqaini.(2013) ,www.psychologymania.com/2013/01/pengertian- single-parent. html. Diakses. Di akses tanggal 15 april 2015.

Pramudya, (2013) Andry, http://zulfaidahidriana.blogspot.com/2013/pengertian-unsurdan-kriteria-masyarakat.html. Di akses tanggal 15 april 2015.

Primasari.,(2009) Pengertian Strategi http://jurnal-sdm.blogspot.com/2009/08/konsepstrategi-definisi-perumusan.html. Di akses tanggal 15 april 2015. 